\title{
PORCELLANID CRABS (CRUSTACEA, DECAPODA) INHABITING SAND REEFS BUILT BY Phragmatopoma lapidosa (Polychaeta, Sabellariidae) AT PARANAPUÃ BEACH, SÃO VICENTE, SP, BRAZIL
}

\author{
MICHELETTI-FLORES, C.V. ${ }^{1}$ and NEGREIROS-FRANSOZO, M. L. ${ }^{1,2}$ \\ ${ }^{1}$ NEBECC (Group of Studies on Crustacean Biology, Ecology and Culture), \\ Departamento de Zoologia, Instituto de Biociências \\ ${ }^{2}$ Instituto de Biociências, Unesp, C.P. 510, Botucatu, CEP 18618-000, São Paulo, Brazil \\ Correspondence to: Maria Lucia Negreiros-Fransozo, Instituto de Biociências, Unesp, C.P. 510, Botucatu, \\ CEP 18618-000, São Paulo, Brazil, e-mail: mlnf@ibb.unesp.br \\ Received October 17, 1997 - Accepted May 04, 1998 - Distributed February 23, 1999
}

(With 7 figures)

\begin{abstract}
The purpose of this study is to survey the porcellanid crab fauna inhabiting Phragmatopoma lapidosa sand reefs at Paranapuã Beach, São Vicente (SP), Brazil, and to assess species diversity, density and spatial distribution at this locality. Monthly samples were carried out from September/94 to August/ 95 in three established sampling sites along the rocky shore. Five species of Porcellanidae were recorded: Pachycheles laevidactylus, P. monilifer, Petrolisthes armatus, Pisidia brasiliensis and Megalobrachium roseum comprising 9,084 specimens. The former four species were recorded in all sampling sites while the latter ocurred only in one. The highest relative density was showed by $P$. laevidactylus followed by $P$. armatus. Remaining species were present in much lower densities, disregarding site or sampling month. In general, higher densities were registered during winter. The species, P. laevidactylus, $P$. monilifer and $P$. armatus showed an heterogeneous habitat occupation along the shore, probably reflecting different tolerance levels against salinity fluctuations.
\end{abstract}

Key words: Porcelain crabs, species diversity, sabellariid reefs.

\section{RESUMO}

\section{Porcelanídeos (Crustacea, Decapoda) associados aos recifes de areia construídos por Phragmatopoma lapidosa (Polychaeta, Sabellariidae) na Praia de Paranapuã, São Vicente, SP, Brasil}

O objetivo do presente estudo é fazer um levantamento da fauna de porcelanídeos que habitam os recifes de areia de Phragmatopoma lapidosa na Praia de Paranapuã, São Vicente (SP), Brasil, e avaliar a diversidade de espécies, suas densidades e distribuição espacial neste local. Amostras mensais foram realizadas de setembro de 94 a agosto de 95 em três pontos preestabelecidos ao longo do costão rochoso. Foram registradas cinco espécies de Porcellanidae: Pachycheles laevidactylus, P. monilifer, Petrolisthes armatus, Pisidia brasiliensis e Megalobrachium roseum, num total de 9.084 espécimes. As quatro primeiras espécies foram registradas em todos os pontos de coleta, enquanto a última ocorreu em apenas um dos pontos. A espécie $P$. laevidactylus apresentou a maior densidade relativa, seguida de $P$. armatus. As demais espécies estavam presentes em densidades muito menores, independentemente do ponto ou mês de coleta. De forma geral, as maiores densidades foram registradas durante os meses de inverno. As espécies $P$. laevidactylus, $P$. monilifer e $P$. armatus apresentaram uma ocupação heterogênea do hábitat ao longo do costão rochoso, refletindo, provavelmente, diferentes níveis de tolerância quanto à variação de salinidade.

Palavras-chave: Porcelanídeos, diversidade de espécies, recifes de areia. 


\section{INTRODUCTION}

The intertidal zone of rocky shores enclose a wide array of microhabitats which are colonized by several organisms. One of this biotopes is formed due to the clustering of sabellariid polychaets. In southeastern Brazil the species Phragmatopoma lapidosa Kinberg (1867), builds extensive sandy reefs by means of aggregating individual compact sand tubes (Amaral, 1987).

P. lapidosa sand reefs occur mainly along the tropical coast of the Americas (Fanta, 1968) and hold a very abundant and diverse associated fauna in which decapod and stomatopod crustaceans, very common worm reef inhabitants, find a hard substratum, shelter and food (Gore et al., 1978). Therefore, the formation of these colonies may be essential for the sustenance of certain crustacean populations living in the surf zone.

Porcelain crabs are mainly composed by coastal species (Coelho, 1963/1964; Veloso \& Melo, 1993), and they are a prevailing group among decapod crustaceans living in these sand reefs. Their association with $P$. lapidosa colonies was previously reported by Gore et al., (1978), Almaça (1990) and Pinheiro et al., (1997), who had mentioned the relative importance of porcelain crabs in these communities. The purpose of the present study is to identify the porcellanid species occurring in P. lapidosa reefs at Paranapuã Beach, São Vicente, SP, Brazil, and to determine their dominance ranking, density variation and spatial distribution along this rocky shore.

\section{MATERIALS AND METHODS}

Monthly samplings were conducted at the intertidal south-facing rocky shore at Paranapuã Beach (Fig. 1) from September/94 to August/95 during low tides. Three different sampling sites were established along the shore, located approximately 60 (site 1), 180 (site 2) and $340 \mathrm{~m}$ (site 3) far from the sandy beach.

In order to determine the sample size, a previous field study was carried out at the same area, in which 40 scattered random samples of about $1 \mathrm{~kg}$ were removed from the rocky surface and processed to separate the porcelain crabs from the sand.

A performance curve considering cumulative mean crab density (dependent variable) and cu- mulative sample weight (independent variable) was graphed according to Brower \& Zar, 1977. In the performance curve obtained, no further significant variations in cumulative mean crab density were recorded beyond $9 \mathrm{~kg}$ cumulative sample weight, which was the established sample size for each site.

Salinity was monthly recorded with a manual refractometer at each site and on December $12^{\text {th }}$, 1994 , a salinity profile was performed after obtaining 19 surface water samples taken at $20 \mathrm{~m}$ intervals along the shore, from the sandy beach to the most distant sampling site. Surface water temperature was also registered each month at each sampling site.

P. lapidosa samples were weighed in an electronic balance to the nearest $0.1 \mathrm{~g}$. After weighing, the samples were completely processed to remove all porcelain crabs. All specimens were identified to species according to Veloso \& Melo (1993).

The Shannon-Weaver diversity index (H'), Evenness (J') and Simpson's dominance index (I) were calculated to each sampling site. Diversity indices were compared with a t-test according to Poole (1974). At each sampling site the constancy ratings of each species were determined according to Silveira-Neto et al., (1976). From the obtained results, the species were rated as constant (occurring in more than $50 \%$ of samples), accessory (from 25 to $50 \%$ ) and accidental (less than 25\%).

\section{RESULTS}

Average surface water temperature at Paranapuã Beach was $24.3 \pm 2.6^{\circ} \mathrm{C}$. Temperature differences between sampling sites were constantly below $1{ }^{\circ} \mathrm{C}$ in the same day. Therefore, temperature readings at each site were grouped and monthly averages were calculated for the whole shore. Fig. 2 shows the variation of mean water temperature throughout the study period. The highest temperature were recorded during summer with a peak in February $/ 95\left(28.7^{\circ} \mathrm{C}\right)$ and the lowest during winter, being the lowest value recorded in July/ $95\left(20.8^{\circ} \mathrm{C}\right)$.

At each site, salinity showed a considerable variation during the study period. Higher variability was found at sampling site 1 , where average salinity $(26.0 \pm 3.7 \%$ ) did not differ from those recorded at sampling sites 2 and 3. Otherwise, 
salinity at site $3(29.3 \pm 2.7 \%$ o was significantly higher than at site $2(23.4 \pm 2.3 \%$ ) (Fig. 3). Punctual salinity values ranged from $19.3 \%$ recorded at site 1 in April/95 to $34.0 \%$ registered at site 3 in December/94. Salinity means and range are quite expected for an area surrounded by a large estuarine complex.

Salinity may also vary notably along the shore in a given day (Figs. 3 and 4). A more detailed salinity profile illustrates the salinity variation along the shore. At December $12^{\text {th }} 1994$, mean water temperature was $26.2^{\circ} \mathrm{C}$ and salinity varied from $24 \%$ at $180 \mathrm{~m}$ (site 2), to $34 \%$ at $340 \mathrm{~m}$ far from the beach (site 3) (Fig. 4).
Five different porcelain crab species (Fig. 5) were found inhabiting sabellariid worm reefs at the study area: Pachycheles laevidactylus Ortmann, 1892 (= P. haigae according to Harvey $\&$ De Santo, 1996), Pachycheles monilifer (Dana, 1852), Petrolisthes armatus (Gibbes, 1850), Pisidia brasiliensis (Haig, 1968) and Megalobrachium roseum (Rathbun, 1900). Besides the species mentioned above, Petrolisthes galathinus (Bosc, 1801) were observed in the study area under rocks. Veloso \& Melo (1993) commented that P. galathinus can be found associated to polychaete colonies but it was never recorded in the samples obtained in the present study.
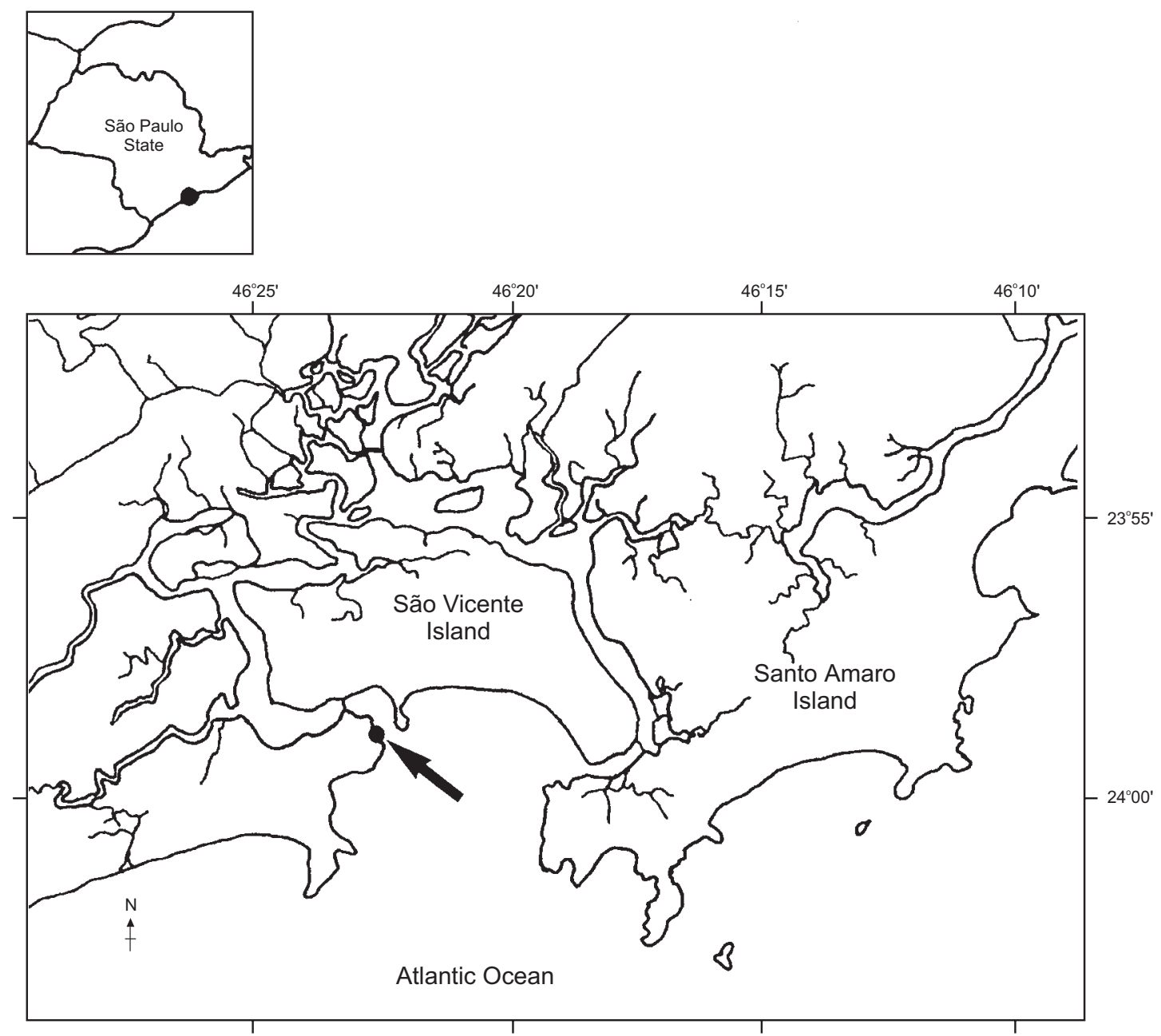

Fig. 1 - Map of the Santos and São Vicente bay-estuary complex. The arrow indicates the location of Paranapuã Beach. 


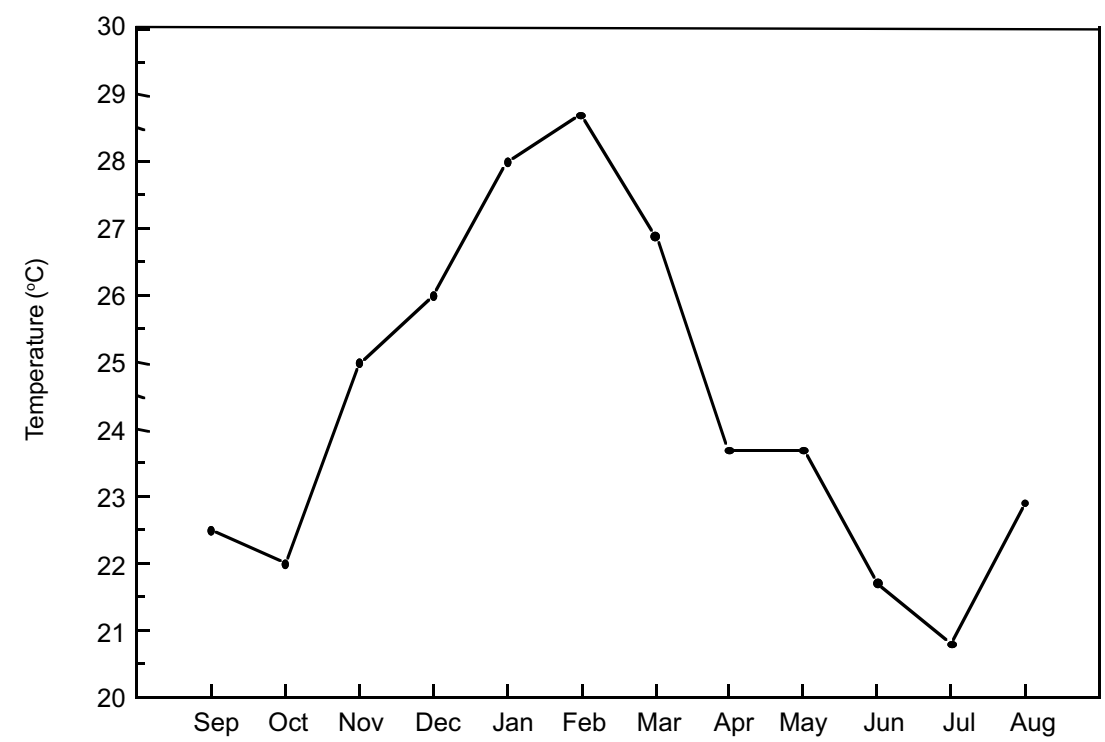

Fig. 2 - Monthly mean values of surface water temperature throughout the study period at Paranapuã Beach, São Vicente, SP.

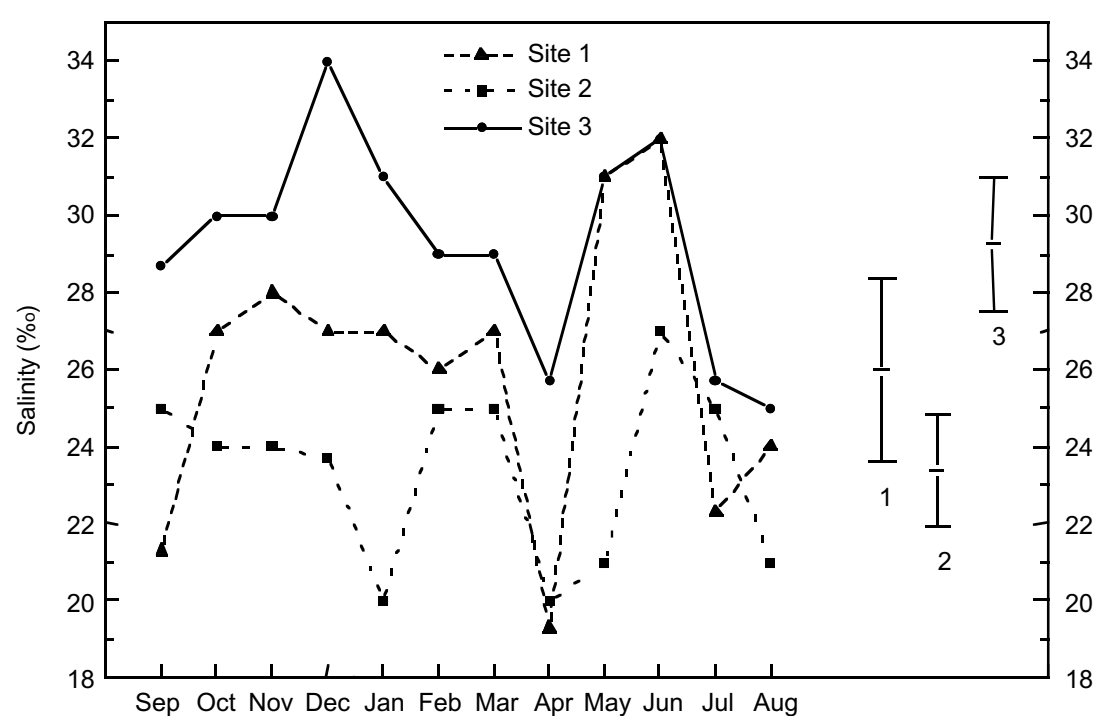

Fig. 3 - Monthly salinity variation along the study period at each sampling site in Paranapuã Beach, São Vicente, SP. Bars indicate $95 \%$ statistical confidence intervals of salinity mean at sites 1,2 and 3 .

From all samples, which comprised $380.7 \mathrm{~kg}$ of sampled material, a total of 9,084 porcelain crabs was obtained corresponding to a mean crab density of 23.9 ind. $\mathrm{kg}^{-1}$. Among the five recorded species, highest densities were observed in P. laevidactylus, representing $64 \%$ of all crabs collected, followed by $P$. armatus which represented approximately $35 \%$. The remaining species were present in much lower densities, i.e., less than 1 ind. $\mathrm{kg}^{-1}$ in all sites and months. Combining all sites, the density of P. laevidactylus was higher than 12 ind. $\mathrm{kg}^{-1}$ in almost all sampling period, ranging from 6.92 ind. $\mathrm{kg}^{-1}$ in March/95 to 21.94 ind. $\mathrm{kg}^{-1}$ in August/95. For $P$. armatus, lower densities were recorded from October/94 to January/95 while the highest densities were verified from May to August/95 (Fig. 6a). 


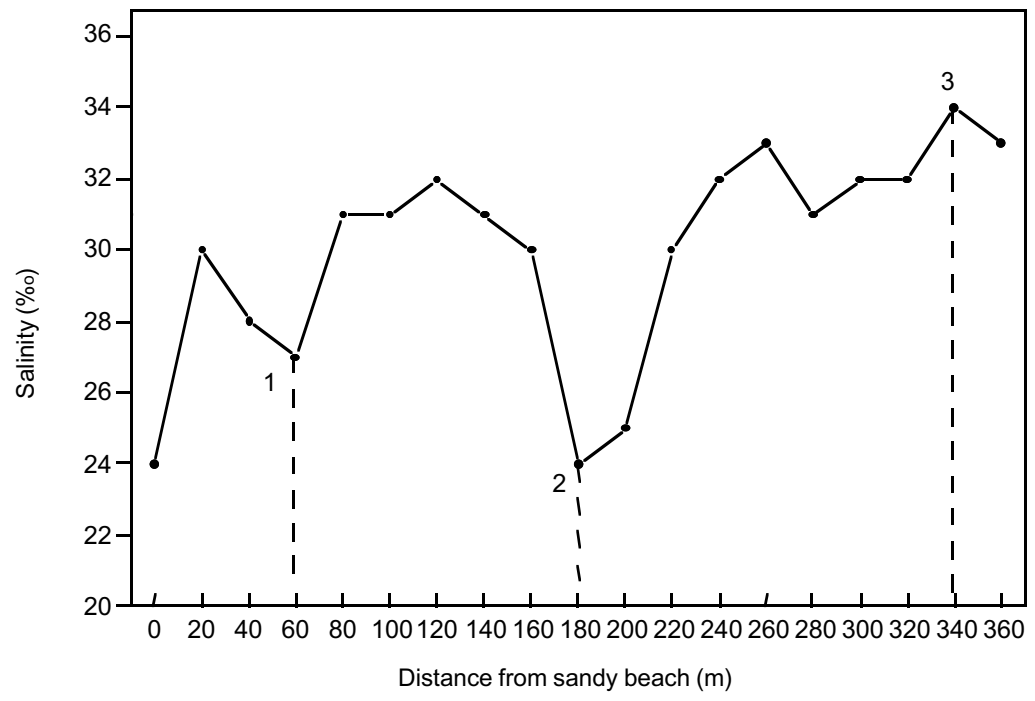

Fig. 4 - Salinity profile of surface water salinity along the south-facing rocky shore at Paranapuã Beach, São Vicente (SP), recorded on $12^{\text {th }}$ December, 1994. The position marked as $0 \mathrm{~m}$ corresponds to the sandy beach location. Numbers indicate sampling sites and dashed lines their respective distance from the sandy beach.

In spite of occurring in much lower densities, $P$. monilifer and $M$. roseum were also more abundant during late autumn to early winter. Only three $P$. brasiliensis specimens were obtained during this study, one in each sampling site in June, July and August (Fig. 6b).

The species $P$. laevidactylus and P. armatus were found in all sampling sites. $P$ laevidactylus was present in higher densities at site 3 ( $\mathrm{p}<0.05$ ). $P$. armatus, was numerically predominant at sampling site 1 , but its distribution along the shore is more homogeneous and no density statistical differences were observed along the shore $(p>0.05)$ (Fig. 7a). P. monilifer was sampled in all sites in relatively small numbers, but its density was significantly higher at site 3 ( $p<0.05)$, which was the only site where M. roseum was found (Fig. 7b).

Shannon-Weaver diversity indices and their respective variances are shown in Table 1 for each sampling site. H' (nits/individual) values obtained in all sites are similar. In spite of this, because of reduced variances in estimating these indices, significant statistical differences were verified between them.

Species diversity in site 1 and 3, which are not significantly different $(\mathrm{t}=1.28 ; \mathrm{p}>0.05)$, are higher than that obtained in site $2\left(\mathrm{H}_{1}, \mid \mathrm{H}_{2}\right.$; $\mathrm{t}=4.69 ; \mathrm{p}<0.001$ and $\mathrm{H}_{3}^{\prime} \quad \mid \mathrm{H}_{2}^{\prime} ; \mathrm{t}=5.18$; $\mathrm{p}<0.001)$. Evenness values, which can not be compared by statistical means, seem to follow the same trend as diversity values, i.e., $\mathrm{J}_{1}^{\prime}>\mathrm{J}_{3}^{\prime}>\mathrm{J}_{2}^{\prime}$. As expected, Simpson's dominance indices ranked in the opposite way (Table 1).

Regarding species constancy, P. laevidactylus and $P$. armatus were classified as constant species at all sampling sites; $P$. monilifer was rated as accidental at sites 1 and 2 and constant at site 3; P. brasiliensis was regarded as accidental at all sampling sites; and M. roseum, which occurred only at site 3, was considered accessory (Table 2).

\section{DISCUSSION}

Examining the environmental factors of the rocky intertidal is very important since they directly affect the fauna associated to sabellariid worm reefs. In this study, it is clear that temperature oscillates in a seasonal basis in which lower values are verified in winter and higher ones during the summer, as previously reported by NegreirosFransozo et al., (1991) in southeastern Brazil. Nevertheless, it should be pointed out that in this study, temperature values may not adequately represent monthly means because no continuous recordings were available. Also analyzing punctual readings, Gianini (1994) found an average yearly temperature $2{ }^{\circ} \mathrm{C}$ higher than the present results at the same area. 

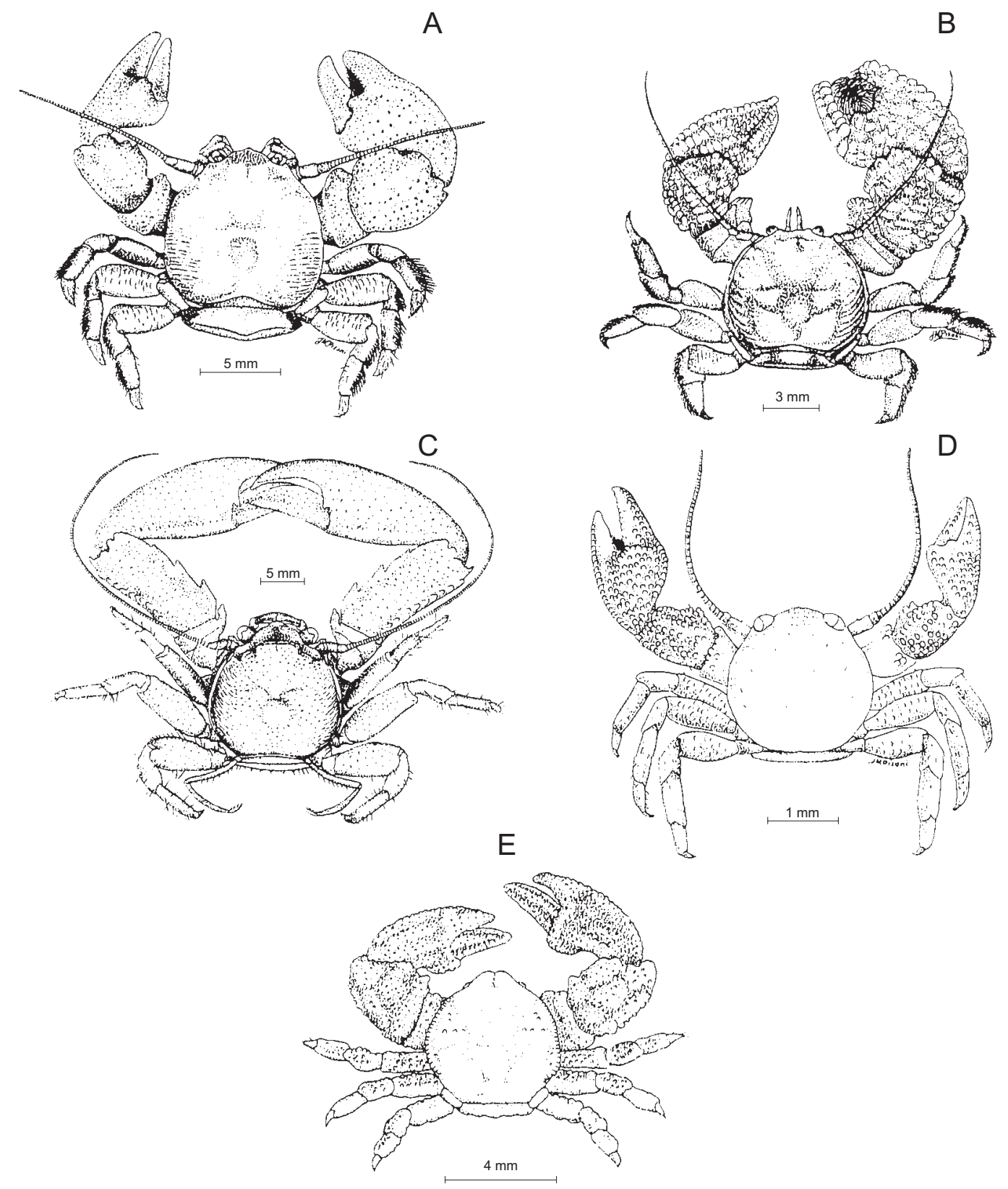

Fig. 5 - Dorsal view of porcelain crab species surveyed in the present study. A: Pachycheles laevidactylus (Ortmann, 1892); B: Pachycheles monilifer (Dana, 1852); C: Petrolisthes armatus (Gibbes, 1850); D: Pisidia brasiliensis (Haig, 1968); E: Megalobrachium roseum (Rathbun, 1900). 

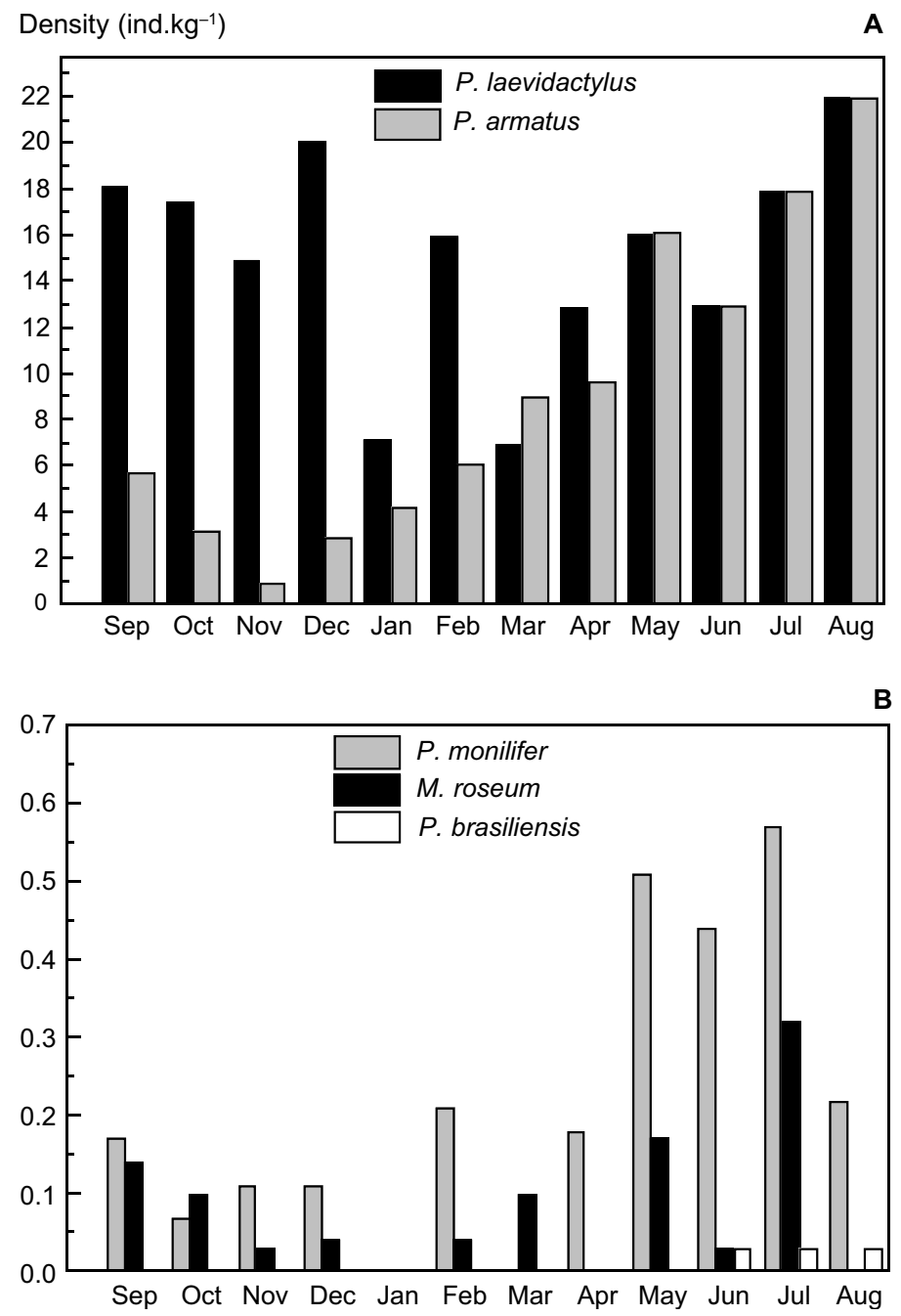

Fig. 6 - Overall density variation of porcelain crabs during the study period. A: Pachycheles laevidactylus and Petrolisthes armatus; B: Pachycheles monilifer, Megalobrachium roseum and Pisidia brasiliensis.

Species longitudinal distribution is commonly influenced by many environmental factors. These factors may act independently or synergistically (Garutti, 1988) and sometimes are difficult to identify.

Even being considered as a major factor ruling species latitudinal distribution, temperature may not be so influencing in smaller scale systems. At the study area, temperature barely varied in a given sample day, and therefore, it is not likely to explain the spatial distribution of porcelain crabs along the shore. Otherwise, a clear salinity gradient due to freshwater drainage from hill creeks at certain sections of the shore can be easily noticed. This salinity gradient is certainly the main factor influencing the spatial distribution of porcelain crabs over this shore, but it can be blurred under conditions of heavy rainfall as occurred during field sampling in July/95, when salinity at site 3 and 1 were considerably lower than average.

Considering the density data obtained, it can be concluded that porcellain crab species inhabiting sabellariid colonies at Paranapuã Beach showed different distributional patterns along the shore. These differences should be tightly related to each species's osmoregulatory capability, which is a factor limiting species's distribution. 
Density (ind. $\mathrm{kg}^{-1}$ )

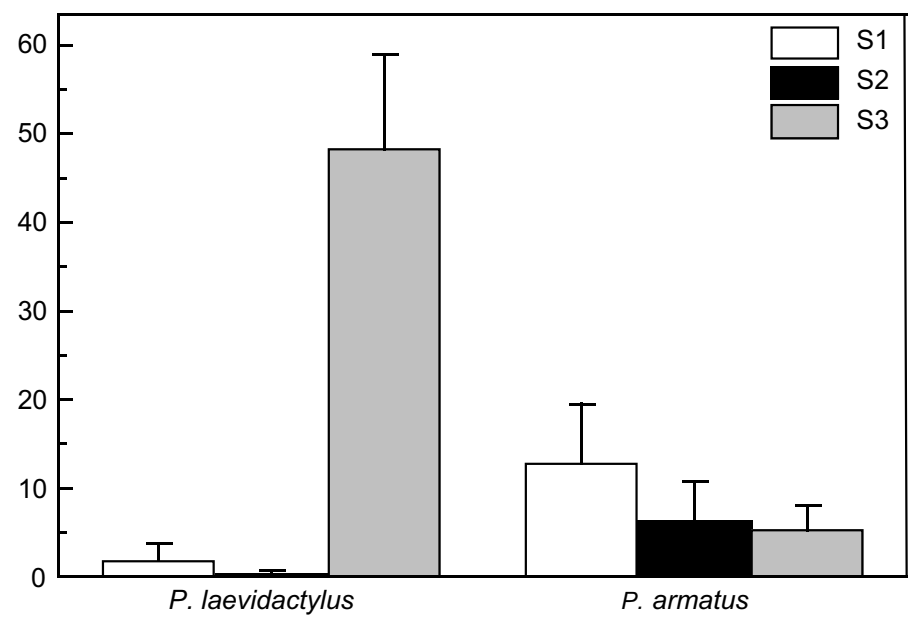

B

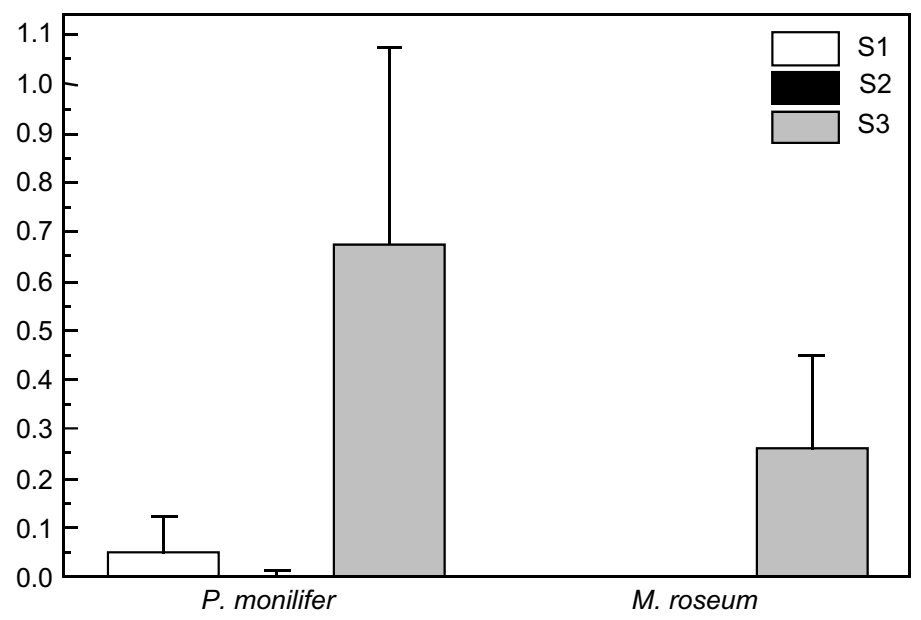

Fig. 7 - Density variation of porcelain crabs at each sampling site. Bars indicate $95 \%$ statistical confidence intervals of mean density. A: Pachycheles laevidactylus and Petrolisthes armatus; B: Pachycheles monilifer and Megalobrachium roseum.

TABLE 1

Shannon-Weaver's index of species diversity (H') and respective variances (var (H')); Evenness (J') and Simpson's dominance index (I), at each sampling site at Paranapuã Beach, São Vicente, SP.

\begin{tabular}{cccc}
\cline { 3 - 4 } \cline { 3 - 4 } \cline { 3 - 4 } Index & Site 1 & Site 2 & Site 3 \\
\hline H' (nits/individual) & 0.43 & 0.30 & 0.41 \\
$\operatorname{var}\left(H^{\prime}\right)$ & 0.0002 & 0.0005 & 0.0001 \\
J' & 0.31 & 0.22 & 0.25 \\
1 & 0.75 & 0.85 & 0.80 \\
\hline
\end{tabular}


TABLE 2

Constancy of porcellanid crab species at each sampling site in Paranapuã Beach.

\begin{tabular}{l}
\hline \multicolumn{1}{c}{ Species } \\
\hline Pachycheles laevidactylus \\
Pachycheles monilifer \\
Petrolisthes armatus \\
Pisidia brasiliensis \\
Megalobrachium roseum \\
\hline
\end{tabular}

\begin{tabular}{ccc}
\hline \multicolumn{3}{c}{ Species constancy } \\
Site 1 & Site 2 & Site 3 \\
\hline 66.67 & 52.78 & 100.00 \\
11.11 & 2.78 & 55.56 \\
97.22 & 100.00 & 91.67 \\
2.78 & 2.78 & 2.78 \\
0 & 0 & 30.56 \\
\hline
\end{tabular}

Significant densities of $P$. armatus at all sampling sites may reflect higher tolerance against salinity variations. Coelho (1963/1964) reported this species in mangrove swamps, Werding (1982) and Oliveira \& Masunari (1995) noted its occurrence in a salinity ranging from brackish to typical salt water, but a density decline is remarkable in salinity conditions below 6.7\% (Oliveira \& Masunari, 1995). P. laevidactylus, P. monilifer and $M$. roseum, which are species probably restricted to the marine environment, seem to be more susceptible to salinity fluctuations, occurring mainly at sampling site 3 . Habitat partitioning between $P$. laevidactylus and $P$. armatus, the two most common species, may also indicate a competition mechanism between these species.

In all species but $P$. laevidactylus, crab density throughout the study period followed a seasonal variation in which higher densities were recorded in winter, when temperature ranged from 20 to $23^{\circ} \mathrm{C}$, and lower ones during warmer months. In southern Brazil, Oliveira \& Masunari (1995) found the opposite trend for the porcellanid $P$. armatus, in which higher densities were observed during summer when mean water surface temperatures were above $25^{\circ} \mathrm{C}$. Smaldon (1972), who investigated the biology of porcelain crabs in the cold temperate north hemisphere, observed that the density of Pisidia longicornis (Linnaeus, 1776) and Porcellana platycheles (Pennant, 1777) declined in summer.

In both Oliveira \& Masunari (1995) and Smaldon (1972), declining population densities were attributed to high mortality rates of older agegroups. Seasonal occurrence of porcelain crabs in the present study may be related to their reproductive activity patterns in the study region (Micheletti-Flores, 1996).
P. brasiliensis and $M$. roseum, which are respectively accidental and accessory species in this habitat, are frequently found associated with the bryozoan Schizoporella unicornis (Johnston, 1874) at Ubatuba, SP, Brazil (pers. obs.). This fact, suggests that these species may preferentially inhabit the infralittoral zone. Records on $P$. brasiliensis included only three very young crabs during winter months, which would indicate an accidental recruitment in sabellariid worm reefs during this season. In the case of $M$. roseum, adult crabs including ovigerous females were obtained in this study, suggesting that this species is capable to settle and remain in these colonies.

There are several models attempting to explain the processes involved in the development of diversity gradients, which are ruled by environmental stability, habitat age, trophic resources stability, competition and predation (Pires, 1992). Diversity can be measured and expressed by a given index and its basic components, which are valuable tools of environmental analysis (Barcellos et al., 1989). Shannon-Weaver's diversity index combines species richness and evenness values (Krebs, 1972). Species richness is the number of species surveyed while evenness reflects the degree of homogeneity regarding relative species density (Poole, 1974).

Evenness values obtained for porcelain crabs inhabiting sabellariid worm reefs at Paranapuã Beach are relatively low according to Legendre $\&$ Legendre, 1983. Low evenness values may indicate strong interspecific competition, in which dominant species are favored compared to others coexisting in much reduced densities. At site 1 , where higher diversity is due to higher evenness values, relative density of species are closer, and therefore, dominance is lower. 
According to Lloyd \& Ghelardi (1964), basic components of diversity can be interpreted from an ecological/environmental approach. Following those authors, while species richness would depend on structural heterogeneity of habitats, evenness would be more susceptible to environmental stability. Based on this theoretical assumptions, It can be inferred that higher diversity at site 1 would be due to a wider array of potentially exploitable ecological niches and higher environmental stability, mainly due to a reduced wave exposure at this site. Otherwise, lower diversity value at site 2 would reflect lower habitat complexity and environmental stability, the latter probably related to reduced salinity caused by freshwater discharge.

The high dominance value obtained at site 2 reflects the predominance of $P$. armatus in that area. At site 3, the occurrence of a few $M$. roseum specimens, which were only observed at this site, shaded the dominance of P. laevidactylus.

The constancy index of a given species is commonly used in studies on the longitudinal distribution of fish in freshwater streams, allowing not only an overview of each species' distribution but also a faunistic characterization of a given sampled site (Garutti, 1988) and an adequate environmental description. Concerning the constancy of porcellanid species at Paranapuã Beach, two major groups can be delimited; Pachycheles laevidactylus, P. monilifer and Petrolisthes armatus are permanent species while Pisidia brasiliensis and Megalobrachium roseum are visitant species. This grouping provides basic information about the relative importance and ecological role of these species in this habitat.

According to Gore et al. (1978) the relative numerical abundance of a species may be a potential indicator of its ecological dominance within the community. By adopting this parameter and the criterion used by Yáñez-Arancibia et al. (1985) to define dominant species in coastal tropical systems, P. laevidactylus can be considered the dominant porcellanid inhabiting sabellariid worm reefs, followed by P. armatus. This results confirm the remarkable importance of porcelain crabs in this specific biotope. Dominant species are capable to successfully exploit a given habitat due to diversified biologic strategies (Tapia-García et al., 1988). Therefore, understanding the biology of such species is essential to a better knowledge of the overall ecology of a certain biotope.

Acknowledgments - We thank Dr. Marcelo A. A. Pinheiro for his helpful comments, Dr. Gustavo de Melo who confirmed our identification of some species and Mr. José Mário Pisani for the species' illustrations. We are also grateful to our colleagues Augusto A. V. Flores, Jelly M. Nakagaki and Álvaro L. D. Reigada for their help during field work. Financial support was provided by CNPq (proc. \# 830347/94-1) as a fellowship awarded to the first author and by Fundunesp (proc. \# 269/93) as a grant.

\section{REFERENCES}

ALMAÇA, C., 1990, Structure and interations in the crab community inhabiting sabelariid worm colonies at Praia de Ribeira D'Ilhas (Ericeira, Portugal). Arq. Museu Bocage, N.S., 1(37): 505-519.

AMARAL. A. C. Z., 1987, Breve caracterização de Phragmatopoma lapidosa (Kinberg, 1867) (Polychaeta, Sabellariidae). Rev. Brasil. Zool. 3(8): 471-474.

BARCELlOS, L. J. P., RIOS, E. C. \& ABRALÃO, R. S., 1989, Micromoluscos do substrato inconsolidado do Atol das Rocas, RN, Brasil: a diversidade como fator de inferência ambiental. Rev. Brasil. Biol., 49(2): 545-552.

BROWER, J. E. \& ZAR, J. H., 1977, Field and laboratory methods for general ecology. Wm. C. Brown Company Publishers, Dubuque, Iowa, $2^{\text {nd }}$ Ed., 226p.

COELHO, P. A., 1963/1964, Lista dos Porcellanidae (Crustacea, Decapoda, Anomura) do litoral de Pernambuco e dos estados vizinhos. Trab. Inst. Oceanogr. Univ. Recife, 5/6: 51-68

FANTA, E. S., 1968, Sobre a biologia e ecologia de Phragmatopoma lapidosa (Sabellariidae, Polychaeta). Ciênc. Cult., 20: 459-460.

GARUTTI, V., 1988, Distribuição longitudinal da ictiofauna em um córrego da região noroeste do Estado de São Paulo, Bacia do Rio Paraná. Rev. Brasil. Biol., 48(4): 747-759.

GIANINI, R., 1994, Estrutura das Comunidades de Peixes da Zona de Arrebentação do Litoral Sudeste do Brasil. Tese de Doutorado, Instituto Oceanográfico - Universidade de São Paulo, São Paulo, SP, 156p.

GORE, R. H., SCOTTO, L. E. \& BECKER, L. J., 1978, Community composition, stability, and trophic partitioning in decapod crustaceans inhabiting some subtropical sabellariid worm reefs. Bull. Mar. Sci., 28(2): 221-248.

HARVEY, A. W. \& SANTO, E. M. de, 1996, On the status of Pachycheles laevidactylus (Ortmann, 1892) (Decapoda: Porcellanidae). Proc. Biol. Soc. Wash., 109 (4): 707-714.

KREBS, C. J., 1972, Ecology: The experimental analysis of distribution and abundance. Harper \& Row Publishers Inc., New York, $2^{\text {nd }}$ Ed., 694p.

LEGENDRE, L. \& LEGENDRE, P., 1983, Numerical ecology developments in enviromental modelling. 3. Elsevier. Sci. Publ. Co., 419p. 
LLOYD, M. \& GHELARDI, R. J., 1964, A table for calculating the "Equitability" component of species diversity. J. Anim. Ecol., 33: 217-225.

MICHELETTI-FLORES, C. V., 1996, Ecologia Populacional de Porcelanídeos (Crustacea, Anomura) em Aglomerados de Phragmatopoma lapidosa (Polychaeta, Sabellariidae) na Praia de Paranapuã, São Vicente, SP. Dissertação de Mestrado, Instituto de Biociências, UNESP, Botucatu, SP, $94 \mathrm{p}$.

NEGREIROS-FRANSOZO, M. L., FRANSOZO, A., PINHEIRO, M. A. A., MANTELATTO, F. L. M. \& SANTOS, S., 1991, Caracterização física e química da Enseada da Fortaleza, Ubatuba, SP. Rev. Brasil. Geoc., 21(2): 114-120.

OLIVEIRA, E. \& MASUNARI, S., 1995, Estrutura populacional de Petrolisthes armatus (Gibbes) (Decapoda, Anomura, Porcellanidae) da Ilha do Farol, Matinhos, Paraná, Brasil. Rev. Brasil. Zool., 12(2): 355-371.

PINHEIRO, M. A. A., BERTINI, G., FERNANDES-GÓES, L. \& FRANSOZO, A. (1997), Decapod Crustaceans associated to sand reefs of Phragmatopoma lapidosa (Kinberg, 1867) (Polychaeta, Sabellariidae), at Praia Grande, Ubatuba, SP, Brazil. Nauplius, 5(2): 77-83.

PIRES, A. M. S., 1992, Structure and dynamics of benthic megafauna on the continental shelf offshore of Ubatuba, southeastern Brazil. Mar. Ecol. Prog. Ser., 86: 63-76.

POOLE, R. W., 1974, An introduction to quantitative ecology. McGraw-Hill - Series in Population Biology, Kingsport Press, USA, 532p.
SILVEIRA-NETO, S., NAKANDO, O., BARBIN, D. \& VILLA-NOVA, N. A., 1976, Manual de Ecologia dos Insetos. Ed. Agronômica "CERES”, São Paulo, SP, 419p.

SMALDON, G., 1972, Population structure end breeding biology of Pisidia longicornis and Porcellana platycheles. Mar. Biol., 17: 171-179.

TAPIA-GARCÍA, M., YÁÑEZ-ARANCIBIA, A., SÁNCHEZ-GIL, P. \& GARCÍA-ABAD, M. C., 1988, Biología y ecología de Cynoscion arenarius Ginsburg, en las comunidades demersales de la plataforma continental del sur del Golfo de México (Pisces: Sciaenidae). Rev. Biol. Trop., 36(1): 1-27.

VELOSO, V. G. \& MELO, G. A. S., 1993, Taxonomia e distribuição da família Porcellanidae (Crustacea, Decapoda, Anomura) no litoral brasileiro. Iheringia, Sér. Zool., (75): 171-186.

WERDING, B., 1982, Porcellanid crabs of the Islas del Rosario, Caribbean coast of Colombia, with a description of Petrolisthes rosarienses new species (Crustacea, Anomura). Bul. Mar. Science, 32(2): 439-447.

YÁÑEZ-ARANCIBIA, A., LARA-DOMÍNGUEZ, A. L., AGUIRRE LEÓN, A., DÍAZ RUÍZ, S., AMEZCUA LINARES, F., FLORES HERNÁNDEZ, D. \& CHAVANCE, P., 1985, Ecology of dominant fish population on tropical estuaries: environmental factors regulating biological strategies and production, 311-365. In: A. Yáñez-Arancibia (ed.), Fish community ecology in estuaries and coastal lagoons, Editora Universitária UNAM-PUALICML, México. 